\title{
The Rise of Summary Jurisdiction in English Criminal Law Administration
}

\section{The Obsolescence of the Criminat Jury}

It may seem extraordinary to the American defenders of trial by jury that a substitute for this time-honored guilt-finding device has actually been found in the very country that gave it birth some six hundred years ago and that nurtured it through centuries of social strife and institutional change. Yet no fact stands out more clearly in any contemporary study of the English system of criminal law administration, nor is there any that is susceptible of more convincing proof.

Criminal statistics are frequently misleading, but in this instance they are both conclusive and eloquent. In England, during 1926, the next to the last year for which statistics are available, no less than 69,695 defendants charged with indictable offenses, roughly $90 \%$ of the total number, were dealt with in courts of summary jurisdiction, leaving only 7,924 to be committed for jury trial at the ligher courts. ${ }^{I}$ It is of especial significance that most of the cases disposed of without juries did not result from trivial infractions of the criminal law, but were prosecutions in serious offenses which, in most jurisdictions of the United States, would be tried before "twelve good men and true." If we take into further account the large number of defendants who plead guilty when their cases are called for trial at the higher courts, it is probable that not over 5\% of the indictable cases in England actually reach juries. As an eminent English jurist told me: "The criminal jury is smoldering to extinction without protest and with but little debate."

The statistics just cited will be more easily understood if we bear in

1 Crmatnat Statistics (1926) Comd. 3055, pp. 104-107. During 1927, 56,275 defendants charged with indictable offenses were dealt with in courts of summary jurisdiction, leaving 7,136 persons to come up for trial at assizes and quarter sessions. See Crinmal Statistics (1927) Cmd. 3301, pp. 104-107.

2 It must not be lost sight of that recent surveys of criminal law administration in the United States have demonstrated that an amazing proportion of criminal cases is disposed of by some method other than trial by jury, a development due in large part to the practice of "bargaining" for pleas of guilty to lesser offenses and to the widespread and indiscriminate use of the nolle prosequi. For a discussion of this matter see Moley, Poirtics and Criminar Prosecution (1929) chs. 7, 8. Moreover, in several states, notably Maryland, Connecticut, Wisconsin, and Michigan, the defendant is permitted, under certain conditions, to waive trial by jury in a felony case and elect trial before the court without a jury. The Baltimore Criminal Justice Coinmission, for example, reports that $93 \%$ of the criminal cases in Baltimore were tried by judges in 1925. This subject is discussed in my article, Trial by Jury (April 1929) Century Magazine, p. 683. See also Oppenheim, Waiver of Trial by Jury in Criminal Cases (1927) 25 MICE L. REv. 695, and Goldberg, Waiver of Jury in Felony Trials (1929) 28 Micr. L. Rev. 163. 
mind that the old common law distinction between felonies and misdemeanors is no longer of vital significance in England. ${ }^{3}$ Crimes are classified as non-indictable and indictable, a practical distinction based upon the mode of trial. When a charge is heard and finally disposed of without the assistance of a jury by justices of the peace sitting in their petty sessional divisions throughout the country, or by stipendiary or metropolitan police magistrates, the case is said to be dealt with summarily and the hearing is called a summary trial. There are, on the other hand, certain offenses of a more serious nature, such as murder or manslaughter, which cannot be heard and determined summarily but must be tried by a judge sitting in conjunction with a petit jury. In such a case all that the justices are permitted to do is to hear the facts at a preliminary examination for the purpose of determining whether there is sufficient evidence to warrant the accused being committed for trial before a judge and jury. If the examining justices do not believe that the evidence disclosed at the hearing is sufficient to put the defendant upon his trial, he is discharged forthwith. But if they reach a contrary conclusion, the prisoner is committed for trial at the higher courts. Before such a case is actually tried, however, there is a formal charge or accusation preferred against the accused by a grand jury, and this charge is called, as in the Umited States, a bill of indictment. The crime for which the defendant is brought to trial is, therefore, for purposes of convenience, described as an indictable offense and the trial itself is spoken of as a trial upon indictment. ${ }^{4}$

In addition to those offenses which can only be dealt with summarily, and those indictable offenses which cannot, under any circumstances, be disposed of except before a judge and jury, there are certain more or

3 Nearly a half-century ago Professor Maitland pointed out that "in course of time the distinction between felonies and unisdemeanors bas become capricious, and of no great suhstance; that is to say, we know little about the punishment that a criminal will get when we know only that lis crime is a felony or (as the case may be) inisdemeanor." See Martiand, Justice and Potice (1885) 16.

4 Some indictable offenses have their origin in the common law while others are the products of legislative enactment. Summary offenses, on the contrary, being solely the creation of statute, are unknown to the common law. This difference arises from the fact that in earlier times the duties of justices of the peace partook more of an adininistrative than of a judicial nature; they were expected to "keep the peace"and bring offenders to justice; they performed, in other words, many duties which are now left to the police. But with the passing of time justices were given judicial powers by legislative enactment: they were authorized to Lear and determine one petty offense after another until today there are an enormous number of criminal matters over which they exercise summary jurisdiction. While every offense at common law is indictable at the suit of the crown, whenever crimmal jurisdiction has been from time to time conferred by statute upon justices of the peace, it has, as a rule, empowered thein to hear and determine offenses in the first instance, without recourse to the slower processes of indictment and jury trial. 
less serious charges for which an alternative procedure is provided. To put the matter in a more specific way, there are certain offenses which, although ordinarily disposed of summarily, may be tried upon indictment

- if the defendant claims trial by jury, and still other offenses which, though frequently tried upon indictment, may be dealt with summarily, if the court thinks it expedient and the defendant consents. The modern tendency of Parliament to increase the number of indictable offenses which may, under such circumstances, be disposed of summarily, is the most significant development in English criminal law administration during the last half-century. On the whole it has commanded popular support. It has resulted in the obsolescence of the jury, speedier trials, greater expedition in the business of the courts, a material saving in public expense, and an elimination of unwholesome publicity in certain classes of cases. May we not in the United States, where there is such widespread dissatisfaction with the admimistration of justice, study with interest and profit this English substitute for the criminal jury, a substitute that is the product of both experiment and experience?

\section{Summary Dispositron of Petty Offenses}

Courts of summary jurisdiction in the counties consist of justices of the peace sitting in petty sessions, as distinguished from quarter sessions. That is to say, counties are divided into petty sessional divisions, and in all such divisions the sittings of the justices out of quarter sessions are termed courts of petty sessions. There are also petty sessional courts for such boroughs as have been granted separate commissions of the peace; and in certain larger provincial cities professional stipendiary inagistrates perform the same duties as county and borough justices. In the metropolis of London, courts of summary jurisdiction are presided over by professional, salaried inetropohitan police magistrates. In the country one justice can conduct a preliminary examination prior to the trial of an indictment, but in most other matters the presence of a bench of at least two justices is necessary in order to constitute a summary court and transact judicial business. Stipendiary and metropolitan police magistrates are empowered to act alone; when other justices are sitting with them they have equal voting powers with respect to any decision of the court. In some of the metropohtan police courts justices are excluded when the police magistrate himself is present. ${ }^{5}$

If the offense is of a class which is made punishable only upon summary conviction, the court must finally dispose of it by convicting the accused, discharging him from custody, or taking such other action as may in the circumstances be authorized. When it becomes necessary to

5 Metropolitan Police Courts Act (1840) 3 \& 4 Vict. c. 84, §§ 4, 6. See also Stipendiaries Sitting With Lay Justices (1918) 82 Jusr. P. 279, (1919) 83 Jusr. P. 1. 
adjourn the hearing, the court may at its discretion either suffer the defendant to go at large, or commit him into custody, or discharge him upon his entering into a recognizance, with or without sureties, for his appearance on the adjourned date. ${ }^{6}$ These petty, or summary offenses cover a wide field and include (1) many of the petty forms of dishonesty and malicious damage; (2) cruelty to amimals; (3) transgressions against ordinances, or by-laws, as they are called; (4) offenses of vagrancy; (5) violations of laws relating to intoxicating liquors, adulteration of food, game, revenue, public health and education, and (6) certain minor assaults. ${ }^{7}$

Procedure at the summary trial of a petty offense is very simple and expeditious. In the great majority of cases there are no lawyers for either prosecution or defense. The magistrate's clerk states the charge to the accused and inquires whether he pleads guilty or not gnilty. If the plea is guilty, the arresting officer takes the stand and briefly states the facts. Contrary to the practice in the United States, it is customary for the witness to remain standing in the box while giving his testimony. Occasionally, where the witness is aged, ill or infirm, a chair is provided. The prisoner stands (or sits, if the court thinks proper in view of the length of the hearing, or other circumstances) in the "dock," or in many instances in front of it. The dock is a stand in the center of the court room, elevated a few feet from the floor and usually partially enclosed by a railing. Lawyers for the defense never stand or sit by the side of the defendant, as in the United States. Solicitors sit at tables immediately in front of the clerk's desk; counsel usually sit on a bench at the clerk's left. Sometimes the solicitor may step up to the dock to talk with the accused, and sometimes communication takes place through the court attendant or by means of notes passed from the dock.

While the officer is trained to tell his story as concisely as possible, he is usually careful to bring out all the material facts. Where further questions are necessary they are put to the witness by the magistrate's clerk, or by the magistrate himself. The accused is then given an opportunity to niake a statenient in his own behalf, if he so desires. His previous criminal record, if any, is furnished by the arresting officer and sentence is inposed upon him by the magistrate. In prostitution cases, and various other prosecutions where the circumstances seem to justify it, it is not unusual for the magistrate to confer witl the probation officer, or "missionary," as he is called, before passing sentence. By this procedure additional information concerning the defendant which may have an important bearing on the matter of sentence, is often secured. Any other

${ }^{6}$ Summary Jurisdiction Act (1848) 11 \& 12 Vict. c. $43, \$ 16$.

${ }^{7}$ See Offenses against the Person Act (1861) $24 \& 25$ Vict. c. $100, \$ 42$. 
testimony relating to the character and record of the prisoner may be received at this time, subject to the court's discretion.

If the accused pleads not guilty the arresting officer states the facts and calls any other witnesses he may have. In ordinary cases the testimony of the police constable is likely to constitute the prosecution's case. The magistrate then invites the accused to ask any relevant questions he may desire of the officer and other witnesses, and inquires whether or not he wishes to give evidence or call witnesses in his own behalf. If he does not wish to give evidence he is nevertheless permitted to make a statement from the dock. Upon the conclusion of the testimony the magistrate either discharges or convicts the accused, or makes any other disposition of the case which the law authorizes. In the event of conviction, the defendant's criminal record, if any, is obtained from the arresting officer and sentence is imposed upon him. It is the usual practice in a summary case for the clerk to keep an abbreviated record of the evidence in a notebook, but no attempt is made to tlirow it into complete narrative form, as is done in the preliminary examination of an indictable offense.

\section{Summary JuRisdiction of Indictable Offenses}

As already indicated, there are certain offenses which, althouglı ordinarily disposed of summarily, may be tried upon indictment at the election of the defendant. This results from a provision of the Summary Jurisdiction Act, $1879,{ }^{8}$ to the effect that when a person charged before a court of summary jurisdiction with an offense in respect of the commission of which he is liable on summary conviction to be imprisoned for a term exceeding three months and which is not an assault may, on appearing before the court and before the charge is gone into, but not afterwards, claim to be tried before a jury. ${ }^{?}$ The law further provides that the summary court must deal with such a case in all respects as if the accused were charged with an indictable offense. Its duty, in other words, is to hold a preliminary examination and determine whether there is sufficient evidence to justify committing the defendant for trial at a higher court.

The accused must, moreover, before any sucli charge is gone into, be informed of his right to demand trial before a jury, and be asked whether he wishes to exercise it. Should the court fail to give the defendant this information a conviction will be quashed, and this is true even though

842 \& 43 Vict. c. $49, \S 17$ (1).

9 In one other instance besides a charge of assault, the right to trial by jury is taken away in statute, namely, the offense of living on the earnings of prostitution under the Vagrancy Act, 1898. See Criminal Law Aznendment Act (1912) 2 \& 3 Geo. V, c. 20, \$7 (2). See also R. v. Rickinson [1917] 2 K. B. 393. 
the accused has pleaded guilty to the charge. In a case where the defendant is in danger of imprisonment for more than three months by reason only of some previous conviction for the same offense, he must be given the option of trial by jury as soon as the fact of the previous conviction becomes known to the court. ${ }^{10}$ Under this section, therefore, some offenses which in normal course are disposed of summarily, may nevertheless be tried upon indictment, if the defendant elects to demand the benefit of such procedure, which he rarely does. Among the more familiar offenses included within this category are keeping betting and gaming houses, drunkenness while in charge of a mechamically propelled vehicle, intimidation, cruelty to children, and offenses under the Dangerous Drugs and Poisons Act, 1923.11

Besides those offenses which may be tried before a jury simply because the possible punishment exceeds three months imprisonment, there is a large and rapidly increasing nuniber of more serious indictable offenses which may, upon the fulfillment of certain conditions, be disposed of summarily. In truth, the modern legislative tendency to enlarge the competence of courts of summary jurisdiction to hear and determine indictable offenses in the first instance has led many thoughtful observers to wonder if it is only a matter of time until the ancient institution of trial by jury will be almost wholly supplanted by the new procedure.

Prior to 1847 courts of summary jurisdiction could try only petty, or non-indictable offenses. In that year Parliament passed a law permitting persons not more than fourteen years of age charged with certain forms of theft to be dealt with summarily, with the consent of the accused. ${ }^{12}$ Such cases had previously been tried ouly before juries. This legislation was frankly experimental and was followed eight years later by an act extending the process of summary trial to adults in some of the less serious types of larceny. ${ }^{13}$ Since that time there has been a slow but steady encroachment upon the province of the criminal jury. Not only have newly enacted offenses of a serious nature been made triable suntmarily with the consent of the defendant, but some of the most common of the old indictable offenses have been subjected to the same alternative niethod of procedure, under conditions rendered fron tinie to time less stringent. In the words of the present Director of Public Prosecutions, Sir Archibald Bodkin: "The history of the development of the summary jurisdiction of justices over indictable cases shows with what trepidation Parhament at first substituted a bench of justices for a jury,

10 R. v. Beesby [1909] 1 K. B. 849.

1113 \& 14 Geo. V, c. $5, \$ \S 2$ (2), 3 (b).

12 Juvenile Offenders Act (1847) 10 \& 11 Vict. c. 82.

13 Criminal Justice Act (1855) 18 \& 19 Vict. c. 126. 
and how as experience produced confidence in that tribunal, summary jurisdiction was from time to time extended."14

Before the close of the nineteenth century it was possible, under prescribed legal safeguards, to try summarily all persons under the age of sixteen years in all cases except homicide. War-time legislation greatly accelerated the movement by permitting justices to dispose of many newly created offenses which forty or fifty years ago would unquestionably have been reserved for trial by jury. The treasonable offense of trading with the enemy, for example, along with certain prosecutions under the Defense of the Realm Acts, could be dealt with summarily. The influence of the same tendencies may be discovered in the Emergency Powers Act, $1920,{ }^{15}$ passed during the period of industrial unrest which followed the World War. By the provisions of this extraordinary measure, as interpreted and acted upon in the Orders in Council issued thereunder in 1921, several new forms of seditious and treasonable acts may be disposed of in the same manner. This statute, which is part of the permanent law of the land, enables the executive at its discretion, subject to approval by Parliament within seven days, to declare a state of emergency for a period as long as one month whenever it believes that "any action has been taken or is immediately threatened by any person or body of persons" which is calculated "to deprive the community, or any substantial portion of the community, of the essentials of life." Regulations framed by the executive in pursuance of its authority and having the force of law, can expand or alter the existing criminal code of the country during the period of the emergency. ${ }^{16}$

Aside from war-time and emergency legislation, however, the provisions of other laws, not designed to be put into operation merely during periods of national stress, have made it possible for the function of criminal juries to be taken over to an increasingly large extent by courts of summary jurisdiction. It may be well at this point in our discussion, therefore, to summarize briefly the circumstances under which the law permits the new procedure to be substituted for the slower process of trial upon indictment.

In the first place, in all cases where a child, that is, a person under

14 Lieck and Morrison, The Crimmar Justice Act, 1925 (1926) foreword by Sir Archibald Bodkin, p. xxv. This volume contains a detailed summary of the successive legislative enactinents by which courts of suminary jurisdiction have been empowered to hear and determine indictable offenses (pp. 3-6).

1510 \& 11 Geo. V, c. $55, \S \S 1-3$.

16 The Emergency Powers Act has been put in force on several occasions, notably during the great general strike of 1926. See the proclamation of April 30, 1926, the 1926 Code of Emergency Regulations and various subsidiary directions and orders in force during this period of emergency, printed in ST. R. \& O. (1926) 485. See also the interesting discussion of this legislation in WIIIOUGHBY AND RoGers, An Introductron to tHe Problem of GovernMtent (1921) 97-100. 
the age of fourteen years, is charged before a court of summary jurisdiction (juvenile courts belong to this category) with any indictable offense other than homicide, the court niay, if it thinks fit, and the parent or guardian of the child does not object, deal with the case sumniarily. ${ }^{17}$ Young persons, or those between the ages of fourteen and sixteen, may also, in all offenses except homicide, be dealt with summarily, if the court deenis such action expedient and the defendants consent thereto, upon being informed of their right to be tried before a jury. ${ }^{18}$

In the second place, under the provisions of the Criminal Justice Act, $1925,{ }^{19}$ the most recent statute deahing with the subject, all previous legislation relating to the powers of courts of summary jurisdiction to try adults for indictable offenses is repealed, the whole procedure is simplified, and a new and enlarged schedule of such offenses triable summarily is enacted. This hist, which applies to adults only, includes a large number of offenses which, before the passage of the law, had been reserved for trial before juries. ${ }^{20}$ Attempts to commit any of the specified crimes, and the offenses of aiding, abetting, counselling, procuring, or inciting their commission, nray also be disposed of according to the same procedure. The punishment inflicted may be imprisonment for a term not exceeding six months or a fine not exceeding $\notin 100$, or both.

Among the most important offenses which may be disposed of summarily under the ternis of the new act are the following: simple larceny ${ }^{21}$ and offenses punishable as such; larceny from the person; larceny and embezzlement by clerks or servants; larceny or embezzlement by civil servants or police officers; larceny in a dwelling house; larceny from ships, docks, vessels, etc.; larceny by tenants and lodgers; obtaining money or goods by false pretenses; receiving stolen property under circumstances which amount to either felony or misdemeanor; obtaining credit by fraud; falsification of accounts; false statutory declarations; demanding property on forged documents; forging a valuable security;

17 Summary Jurisdiction Act (1879) $42 \& 43$ Vict. c. $49, \S \S 10-11$.

18 Summary Jurisdiction Act (1899) $62 \& 63$ Vict. c. $22, \$ 2$. The powers of the court as to punishment of both children and young persons are regulated by the Children Act (1908) $8 \mathrm{Edw}$. VII, c. 67, $\S \S 102-110$. See also the Criminal Justice Administration Act (1914) 4 \& 5 Geo. V, c. 58, §§ 10-11.

$1915 \& 16 \mathrm{Geo}$. V, c. 86.

20 For a list of these offenses see Lieck and Morrison, The Crimtnat Justice Acr, 1925 (1926) appendix II, p. 103.

21 The expression "simple larceny," as Lieck and Morrison, The Crminnal Justice Act, 1925, supra note 20, point out, has received no legislative definition. "It originally meant larceny other than larceny from the person, or in a dwelling house, under a specified value, which has varied from time to time and is now \pm 5 . Later the meaning was gradually evolved of 'larceny for which no special punishment is by statute provided.' This meaning is adopted in the Larceny Act of 1916 (6 \& 7 Geo. V, c. 50) and, by implication,' in the present Act." See also Stephen, A Digest of the Crominat, Law (7th ed. 1926) 337-8. 
destroying, cancelling or obliterating a valuable security; certain specified offenses against the postal laws; certain specified offenses against the coinage; malicious damage and arson of crops; assaults occasioning bodily harm; wounding or inflicting grievous bodily harm; indecent assaults on children or young persons under the age of sixteen years; attempted suicide; and indecent or obscene publications.

One provision of the act is of particular importance since it deals with the drunken motorist, a type of offender which has becoine increasingly prevalent within recent years. "Any person who is drunk while in charge on any highway or other public place of any mechanically propelled velicle shall," the act reads, "on summary conviction, be liable in respect of each offense to imprisonment for a period not exceeding four months or to a fine not exceeding $£ 50$, or to both such imprisonment and fine."22 The importance of this provision lies in the fact that by the substitution in committee of "four months" for "three months" as the maximum punishment, the motorist has secured the right to demand trial by jury under section 17 of the Summary Jurisdiction Act, 1879.23 This provision creates a new offense, since persons found drunk in charge of motor cars were formerly dealt with under statutes relating to drunkenness in charge of carriages, or stage or hackney carriages. The action of Parhament was doubtless prompted by the view that in cases of this sort evidence is likely to be introduced of a most contradictory and confusing character, and should, if the defendant so elects, be passed upon by a jury.

Finally, im addition to those indictable offenses specified in the second schedule of the Criminal Justice Act, there are, under the provisions of certain modern statutes, offenses against these statutes which are made triable either summarily, or upon indictment, at the will of the prosecutor, controlled by the court. ${ }^{24}$ When such an offense comes before a

$22 \S 40(1)$.

23 See (1926) 161 Law T. 91.

24 The Bankruptcy Act (1914) 4 \& 5 Geo. V, c. 59 is the outstanding instance of this type of statute. Any felony or misdemeanor under that Act in respect of which no specific penalty is imposed may be tried either summarily or upon indictment. Where the former method is resorted to, punishment upon conviction inay be imprisonment with or without hard labor for a term not exceeding six months. In practice a large proportion of bankruptcy offenses is tried summarily. Sce Crtarnat Statistics (1927) Cmd. 3301, pp. 16-19. Under the Newspaper Libel and Registration Act (1881) $44 \& 45$ Vict. c. 60,85 , courts of summary jurisdiction have the power to deal with certain less serious cases of libel in newspapers and may impose fines not exceeding $£ 50$. Under the Inebriates Act (1898) 61 \& 62 Vict. c. 60, an habitual drunkard, after having been three times convicted summarily of committing certain offenses set forth in that Act, can be ordered to be detained in a certified inebriate reformatory for three years. This section, however, is practically obsolete since the treatment is rarely, if ever, resorted to. Persons convicted of offenses against the Dangerous Drugs and Poisons Act (1923) 13 \& 14 Geo. V, c. $5, \S \S 2(2), 3$ (b), are liable (whether tried summarily or upon indictment) to a 
court of summary jurisdiction the prosecution states whether it desires a committal for trial by jury or whether it is content to have the case dealt with summarily. Subject to the consent of the court, the prosecution thus determines, in the first instance, the mode of trial. But in some cases, as in offenses against the Bankruptcy Act, 1914, the maximum punishment on summary conviction is more than three months imprisonment; section 17 of the Summary Jurisdiction Act, 1879, therefore comes into play and the defendant must be given the option of bemg tried by a jury. If he claims his right to a jury trial the case is dealt with as a preliminary examination into an indictable offense. If, on the other hand, both prosecution and defense are desirous of summary trial, and the court sees no objection, the case proceeds summarily.

The Criminal Justice Act provides that the defendant must be informed of his right to be tried by a jury and must be given the opportunity of deciding whether or not he prefers to be dealt with summarily. He may, of course, plead guilty if he so desires. Before resorting to a summary trial, moreover, the court must be convinced such action is expedient. It must consider the nature of the crime, the "character and antecedents" of the prisoner, and the adequacy of the pumishment which it has the power to inflict. ${ }^{25}$ Where the case affects the property or affairs of the Crown, that is, any executive department, or of a public body, ${ }^{26}$ the court cannot deal with the case summarily without the consent of the prosecutor. And where the proceeding is being carried on by the Director of Public Prosecutions, the court cannot deal with the case summarily without the consent of the Director. ${ }^{27}$

If at any time during the preliminary hearing the court becomes satisfied that it is proper to assume jurisdiction of the case, the charge is reduced to writing and read to the accused and the following question put to liun: "Do you desire to be tried by a jury, or do you consent to the case being dealt with summarily?"28 This query is accompanied, in some

fine not exceeding $£ 250$, or to imprisonment with or without hard labor for a term not exceeding twelve months, or both. This sentence is, incidentally, the nost severe punishment that a court of summary jurisdiction can impose.

$25 \$ 24(1)$.

28 As defined by section 7 of the Public Bodies Corrupt Practices Act (1889) 52 \& 53 Vict. c. 69 , "the expression 'public body' means any council of a county or of a city or town, any council of municipal borough, also any board, cornmissioners, select vestry, or other body which has the power to act under and for the purposes of any act relating to local government, or the public health, or to the poor law or otherwise to administer money raised by rates in pursuance of any public general act, but does not include any public body as above defined existing elsewhere than in the United Kingdom." The expression also "includes, in addition to the bodies mentioned in the last inentioned Act, local and public authorities of all descriptions." Prevention of Corruption Act (1916) $6 \& 7$ Geo. V. c. 64, $\$ 4$ (2).

$27 \S 24$ (1) (a) (b).

$28 \S 24(2)$. 
instances, with an explanation of the meaning of a summary trial and the difference between such procedure and trial upon indictment. If he waives a jury trial, the clerk asks him whether he pleads guilty or not guilty. If he admits the charge, the court calls for a statement of the circumstances, which may or may not be on oath, hears the report of the arresting officer as regards his record and character, invariably of a detailed and inpartial nature, and assesses punishment. Where the prisoner denies the accusation, the prosecutor and his witnesses are heard. If the complainant is represented by solicitor or counsel, the conduct of the prosecution will be left in his hands. If legally unrepresented, the prosecutor may conduct his own case, although in such an event he is usually assisted in the examination and cross-examination of witnesses by the clerk and the presiding justice or magistrate. Where the complainant is represented by counsel, it is usual for the latter to make a brief statement to the court outlining the facts which he intends to establish. The witnesses for the prosecution are then called, and if the defendant has no lawyer it is the duty of the court to remind him of his right to crossexamine each witness, and if necessary to assist him in the task.

The defendant is then called upon for his defense, if he desires to present any. He is informed of his right to testify under oath in his own behalf, comment on the evidence for the prosecution, make any unsworn statement he pleases from the dock in justification of his actions, or bring forward any witnesses to substantiate his version of the facts. If the accused is the only witness for the defense, he inust give his evidence immediately after the close of the case for the prosecution; if there is other testimony he need not take the stand until after it has been introduced. The prosecutor is not entitled to reply unless some point of law has been raised for the defense. But if the defendant has called witnesses, other than those as to character only, the prosecutor is permitted to introduce evidence in rebuttal. Upon the conclusion of the testimony no further discussion, except on points of law, is allowed. The court then considers the evidence and either convicts or acquits the accused. In a court presided over by justices of the peace it may sometimes happen that there is an equal division of the court; in such an event the information may be dismissed, but the more usual course is to adjourn the case for a rehearing before a reconstituted court. In the event of conviction the defense lawyer, if there is any, is given an opportunity to state any extenuating circumstances he thinks may have a bearing on the sentence. The practice varies from court to court as to what record is made of the evidence. In some jurisdictions the clerk takes a longhand record, or statement in narrative form, of all the relevant evidence. In others the record is much more abbreviated or possibly not kept at all. There is no stenographic report of the hearing. 
The trial is conducted informally and expeditiously, but the spectator feels that justice rather than speed is the desideratum. It has the appearance of a serious and dignified official investigation into the facts rather than a game of wits between two opposing sides with the court essaying the role of referee. In the majority of cases no lawyers appear for either prosecution or defense. This is one of the chief reasons why the ordinary summary proceeding consumes so much less time than a trial upon indictment. In those cases where lawyers participate, however, there is no attempt to conceal relevant evidence on the part of either side, no bellowing at witnesses, no dilatory tactics, no derogatory references to the accused, no appeals to the galleries, no judicial scolding, relatively few objections to testimony, and virtually no wrangling between opposing counsel. The court, or the clerk, frequently asks questions in order to clear up doubtful points and effectually terminates any attempt to befuddle the witnesses or obscure the issues. Logic and common sense prevail instead of rhetoric and confusion. ${ }^{29}$

\section{Appeals From SUMrMary CoNviction}

Persons convicted summarily may, under the provisions of certain statutes, appeal to a court of quarter sessions on grounds of fact or law, or against sentence only; a further appeal may be taken from the judgment of the court of quarter sessions to the High Court, on a point of law only.

In the year 1927 there were 240 appeals to quarter sessions against convictions or criminal orders made by courts of summary jurisdiction. In 169 cases the conviction or order was affirmed, the sentence being modified in 59 cases; in 63 cases the conviction or order was quashed; and in 8 cases the appeal was abandoned. ${ }^{30}$ Considering the fact that in

20 It should be mentioned that under the Probation of Offenders Act (1907) 7 Edw. VII, c. 17, $\$ 1$, a court of summary jurisdiction, in a case where it thinks the charge is proved, but having regard for certam specified circumstances, considers it inadvisable to impose sentence, may "without proceeding to conviction" dismiss the information or charge, take the recognizance of the offender to keep the peace, or to be of good behavior, or to come up for judgment if called upon to do so; and it unay place the defendant upon probation for a period of time. When any of these courses is taken by the court, therefore, the defendant is placed in the somewhat anomalous position of not being technically convicted, although bound, of course, to fulfill the obligations which the court has seen fit to impose upon him. Commenting upon this provision Mr. Justice Darling said: "The words of section 1 of the Probation of Offenders Act, 1907, are unscientific, thoroughly illogical, and are merely a concession to the modern passion for calling things what they are not; for finding people guilty and at the same time trying to declare them not guilty." Oaten v. Auty [1919] 2 K. B. 278.

30 Crintriar Statistics (1927) Cmd. 3301, p. 85. In 1926 there were 482 appeals to quarter sessions against convictions or criminal orders made by courts of summary jurisdiction; in 348 cases the conviction order was affirmed, the sentence being modified in 162 cases; in 119 cases the conviction or order was quashed; and in 15 cases the appeal was abandoned. Crmminal Statisisics (1926) Cmd. 3055, p. 85. 
this same year there were 538,387 persons convicted (of both nonindictable and indictable offenses), and that criminal orders were made without conviction in 85,116 cases, the number of appeals to quarter sessions seems very slight.

By the Criminal Justice Administration Act, 1914, ${ }^{31}$ a person convicted by a court of summary jurisdiction may appeal to quarter sessions on grounds of fact or law in all cases where he did not plead guilty or admit the truth of the information. This right may be exercised by defendants convicted of indictable offenses which have been disposed of summarily, as well as those found guilty of summary offenses. And where a court of petty sessions has, "without proceeding to conviction" made an order under section 1 of the Probation of Offenders Act, 1907, dismissing the charge, or releasing the defendant on probation, or ordering him to enter into a recognizance, the defendant may, if he did not plead guilty, appeal to quarter sessions against such order, just as if a judgment of conviction had been entered against him. ${ }^{32}$

The rules provide that the appeal must be made to the prescribed court of quarter sessions, or, if no court be prescribed, to the next practicable court having jurisdiction and held, in any case, not less than fifteen days after the decision upon which the conviction or order was founded. ${ }^{33}$ The appellant must, within the prescribed time, or, if no time be prescribed, within three days after giving notice, enter into such recogmizance as a court of summary jurisdiction may direct, conditioned to appear and try the appeal, abide the result, and pay such costs as may be awarded; or he may, by permission, give security by deposit of money. ${ }^{34}$

It is worthy of note, therefore, that if you are convicted and sentenced to a month's imprisonment by a magistrate, you must, in order to perfect an appeal, find a surety who will undertake not only to produce you on the date when the appeal is to be heard, but to pay the costs up to the amount of the bond in the event the appeal is unsuccessful; but if you are convicted of murder at the assizes or the Central Criminal Court, you can appeal to the Court of Criminal Appeal without costs to either prosecution or defense. ${ }^{35}$

In every appeal to quarter sessions against conviction there is a trial de novo, all evidence being taken afresh just as if there had been no previous hearing. The appellate jurisdiction of quarter sessions, unlike

$314 \& 5$ Geo. V, c. $58, \$ 37$.

32 Criminal Justice Act (1925) $15 \& 16 \mathrm{Geo}$. V, c. 86, $\$ 7$ (1), as amended by the Crimmal Justice (Amendment) Act (1926) $16 \& 17 \mathrm{Geo}$. V, c. 13, \$1.

33 Summary Jurisdiction Act (1879) 42 \& 43 Vict. c. $49, \$ 31$.

34 Ibid.

35 This situation has given rise to considerable adverse comment and may be cured by legislative enactment in the near future. 
that of the King's Bench Division, is not limited to questions of law. Upon hearing the appeal the court may confirm, reverse or modify the decision appealed from, or may remit the matter with its opinion thereon, or make such other order as it may think right; and such order has the same effect, and is enforced in the same manner, as if it had been made by the court of summary jurisdiction; it may also make such order as to costs as it may deem just. ${ }^{36}$

A defendant who has pleaded guilty to a summary or an indictable offense in a court of summary jurisdiction may, under the provisions of the Criminal. Justice Act of 1925, appeal against his sentence, although not against his conviction. ${ }^{37}$ In the metropolis any person may appeal agamst an order or conviction of a police magistrate where a penalty of more than $£ 3$, exclusive of costs, or a sentence of more than one month's imprisonment, has been imposed.

In all cases where a question of law is involved, the decision of the justices in petty sessions may be reviewed by the King's Bench Division of the High Court. ${ }^{38}$ Either party, prosecutor or defendant, who desires to question such decision on the ground that it is erroneous in point of law or in excess of jurisdiction, may, within seven days, apply to them to state a case for the opimon of the High Court. The case will set forth the facts and the grounds on which the proceeding is questioned. In the High Court it will be heard by a divisional court on the Crown side of the King's Bench Division; or, in other words, by a court consisting of three judges of that division. If the justices believe that the application is frivolous they may refuse to state a case, unless the application be made by the Attorney-General. In such an event, the person wishing to appeal may apply to the High Court for a rule to compel them to do so, should there appear to be no sufficient ground for their refusal. Such a rule may, of course, be either granted or refused by the High Court, depending on whether or not it believes the point to be frivolous. The appellant is obliged to enter into a recognizance to prosecute his appeal, to submit to the judgment of the High Court, and to pay any costs which may be awarded; he may then, if in custody, be liberated forthwith. Upon adopting this method of appeal, the defendant loses any privilege of appeal to quarter sessions which he might otherwise liave had.

After the determination by a court of quarter sessions of any appeal against a conviction by a court of summary jurisdiction or the sentence imposed on such a conviction, either party to the proceedings may, if dissatisfied with the determination of the appellate court as being erroneous in point of law, make an application in writing to such court at

36 Summary Jurisdiction Act (1879) \$31.

$37 \$ 25$.

38 Summary Jurisdiction Act (1879) $\$ 33$. 
any time within seven days after the date of the determination of the appeal, to have a case stated for the opinion of the High Court on the point of law. If the court of quarter sessions is of opinion that the application is frivolous, it may refuse to state a case; in this event the applicant may apply to the High Court for a rule calling on the court of quarter sessions and the other party to the proceedings to show cause why a case should not be stated, and the High Court may make such order on the application as it thinks fit. ${ }^{39}$

\section{Summary Jurisdiction or Trial by JURy?}

With all its advantages, the operation of the Criminal Justice Act has not been entirely free fron criticism. It is not uncommon, in talking with those who believe in the justice and efficacy of trial by jury, to hear the view set forth that Parliament has been badly advised in increasing, rather than decreasing, the powers of what is, in most jurisdictions, a lay magistracy. The fact that under existing legislation many serious crimes which were formerly reserved for trial at the higher courts may now be disposed of summarily, creates, in their view, an unfortunate and dangerous situation. There are a few High Court judges, for instance, who have expressed the opinion that justices frequently place too liberal a construction on their powers under the law with the result that many cases are dealt with summarily which, because of their importance or difficulty, should be tried before juries. The complaint is sometimes heard, moreover, that in order to bring the case within the jurisdiction of the justices there is a tendency on the part of the police, the prosecutor and the court itself to ignore its more serious elements and to deal with it on a less serious basis, with the result that the culprit is inadequately punished. For example, where the circumstances justify a charge of burglary it is said that the charge may be reduced to "larceny in a dwelling house" in order to make it cognizable by the justices and enable the defendant to waive trial by jury. 40

39 Criminal Justice Act (1925) $\$ 20$ (1) (3) (4).

40 The law is that any person who breaks and enters any dwelling house or certain other specified places and commits any felony therein, or breaks out of the same, having committed a felony therein, is guilty of felony and is liable upon conviction to a maximum sentence of penal servitude for fourteen years. Larceny Act (1916) $6 \& 7$ Geo. V, c. 50, §26; Stephen, A Digest of the CrIminal Law (7th ed. 1926) 347. This offense must be tried upon indictment before a jury. But there is another offense known as "larceny in a dwelling house" which is also a felony and which consists of stealing in a dwelling house any chattel, money or valuable security, if the value of the property stolen amounts to $£ 5$; and a person found guilty of such an offense is liable to a inaximum sentence of penal servitude for fourteen years. Larceny Act (1916) $\$ 13$ (a) ; Stephen, A Digest of the Cromonar Law (7th ed. 1926) 331. The latter offense, however, happens to be one of those which, under the Criminal Justice Act of 1925, may be tried summarily; and it will he recalled that upon conviction the court can inflict no greater punishment than imprisonment for six inonths and a fine of $t 100$, or both. What is charged as frequently happening is 
It is not difficult to understand the motives of the prosecution in such cases. They are similar to those of any prosecuting official in the United States who accepts a plea of guilty to a lesser offense than that with which the defendant has been indicted. The case is disposed of without delay, with less trouble and expense, and with no material witnesses left to disappear or suffer a lapse of memory during the interval between the committal and the trial. Every prosecuting official knows that there is a considerable amount of risk involved in a jury trial, from the standpoint of the state. The defendant may secure the services of a clever lawyer; or the jury may take a dislike to the police officer or to the witnesses for the prosecution; or is apt to be unduly influenced by sympathy for the defendant, or prejudice against the law which makes the thing he is alleged to have done a crime, or by the thought of the punishment he is likely to undergo as a result of his conviction.

There are, in short, a multitude of more or less extraneous issues which may be injected into the minds of the jurors and which may lead them to take a more lement view of the matter than the facts would seem to justify. American prosecuting attorneys are familiar with these elements in the situation and any one of them, if he is talking with you candidly and not for effect, will tell you that in the great majority of cases, and in the absence of special circumstances which make it imperative to bring the defendant to trial, he would prefer to dispose of the case by plea, although the plea may be to a less serious offense than that for which the defendant would have to stand trial, or to a lesser degree of the same crime. I do not argue that this may not be, especially under certain conditions, a bad way of disposing of the case; what I do say is that it is a very common way of disposing of it and that it is a way which will continue to commend itself to prosecuting officials so long as conditions remain what they are today. ${ }^{\mathbf{1 1}}$

The sum and substance of the whole matter is that when the English police get a case disposed of in the court of summary jurisdiction their troubles are over; they are more interested in conviction than in punishment, and if the trial in that court results in an acquittal they can console themselves with the thought that it is fairly certain there would have been no conviction had the same issues been submitted to a jury.

that the police, in order to get the matter disposed of as expeditiously as possible, charge the defendant with the commission of the offense which may be dealt with summarily, rather than the more serious crime. Housebreaking, therefore, is treated as larceny, and attempting to pick pockets becomes loitering in a street with intent to commit felony. There are, in truth, an almost imcredible number of ingenious devices which may be used to bring a comparatively serious charge within the jurisdiction of the justices. See the interesting article, Lieck, Obsolescence of the Jury in Criminal Cases (1924) 157 Law T. 308.

4 On this subject, see Molex, Poltics and Cramatat Prosecution (1929) c. 8. 
The considerations influencing the defendant are even more powerful. If the nature of the offense or the circumstances of its commission has aroused popular prejudice in the community, he is likely to fear its effects on the jury and will prefer being dealt with summarily. Under such conditions trial by the court offers an escape from some of the evils of "trial by newspaper." Nor is that all. Where the prisoner realizes that the case against him is a strong one he will be inclined to elect trial by the justices, with the certainty of a moderate punishment upon conviction, rather than take his chances before a jury with the possibility of a more severe sentence being meted out to him by the higher court. In some instances, it is said, there is an understanding between the police and the defendant that if the case is brought within the jurisdiction of the justices, a plea of guilty will be forthcoming. At all events clerks in the police courts are practically unanimous in their testimony not only that defendants display a marked readiness to be tried by justices, but that there seems to be a marked tendency to plead guilty and "have it done."42 The story is told of a London police court magistrate who had a pickpocket brought before him on the day after his own gold watch was stolen. Upon hearing the charge his indignation flamed up, and without listening to a word of evidence or ascertaining whether the prisoner desired a jury trial, sentenced lim to three months hard labor. The offender took it gleefully, having a "sure fire case" against him and a list of convictions which would have insured him penal servitude for a long period.

It is true that before an indictable offense can be dealt with sumnuarily, the justices must be convinced that such disposition is expedient and will, in view of all the circumstances, promote the ends of justice. As already indicated, they are in duty bound to consider the character and antecedents of the accused, the absence of circumstances which would render the offense one of a grave or serious nature, and the adequacy of the pumishment which they have the power to impose. But experience seems to demonstrate that courts of summary jurisdiction have a tendency to place a liberal construction on their powers under the new Act. The complaint is frequently heard that inferior courts seem to think that because the law gives them the authority to deal with indictable offenses, they are obliged to exercise it whenever the occasion presents itself.

42 Of the 69,695 persons who were charged with indictable offenses and tried summarily during the year 1926,33,314 were convicted; the charges against 28,729 of them were found to have been proved and orders were made in all such cases without proceeding to conviction, under section 1 of the Probation of Offenders Act, 1907; the number acquitted were 7,652. Pleas of guilty and findings of guilty, on the evidence, are not discriminated im either case and there is, therefore, no means of ascertaming the exact number of such pleas. Pleas of guilty unquestionably form a high proportion of the total. 
Many who do not object to the legislation in itself, or the theory upon which it is predicated, believe that in actual practice the powers which it confers upon magistrates have been too freely exercised. That some judges are of the opinion that the results of the law are not all unmixed blessings, and that they look with disfavor on the decreased size of calendars at assizes, is shown by the remarks recently attributed to $\mathrm{Mr}$. Justice Roche of the King's Bench Division:

"At the opening of the Worcestershire Assizes at Worcester on January 26, Mr. Justice Roche made some observations concerning the Criminal Justice Act of 1925. That Act gave magistrates at Petty Sessions power to deal summarily with offenses of a graver character than could be dealt with before. He was satisfied that grave misconceptions had arisen by reason of this Act, and, since he had made observations on various occasions, he had consulted other judges, and he gathered that the general feeling was that a good deal of mischief was resulting. 'May' had been in some cases interpreted as 'should' or 'must'. The Act said nothing of the sort. The practice of dealing summarily with serious effenses was, said his lordship, becoming far too common. The section of the Act which was most material (section 24) stipulated what elements should be present before the jurisdiction of magistrates should be exercised. The phrase summing up the matter was that there must be an absence of circumstances which would render the offense one of a grave and serious character. What that came to was this: that it must be an exceptional case which should be dealt with summarily if it was one of the graver classes of offense. It might be easier sometimes to deal summarily with a matter; he could see, for example, that it might save the clerks and others in the courts a good deal of writing and trouble, and it might be conceived by some people to be economical; those were false notions. There was nothing to be gained by treating grave matters as light, and matters which were serious as though they were not. The inevitable result was that that which was treated with levity would be regarded with levity by the population, and they would have a decline of that respect for law and order and observance of the law which was so desirable."43

Besides its alleged tendency to cause grave offenses to be dealt with on a less serious basis, another objection sometimes advanced against the summary disposition of indictable cases is that under it the interests of the defendant are less adequately protected. This objection is not based on the belief that there is any conscious attempt on the part of those who administer the law to deal unfairly with the accused. Still less does it presuppose that the law itself deprives the prisoner of any constitutional right or privilege possessed by him before its enactment, since no case can be dealt with summarily without his consent. What is maintained is that in a very real, as distinguished from a legal sense, the undeniable effect of this type of legislation has been to cause an enormous number of defendants charged with serious violations of the crimi-

43 (1928) 65 LAw Jour. 104. For a short discussion of Mr. Justice Avory's criticism that charges were being reduced in order that they might be dealt with summarily or at quarter sessions see (1928) 65 LAW Jour. 412. 
nal law, and who are in many instances legally unrepresented, to be tried in a manner which is almost necessarily neither as formal, solemn, careful, searching or impartial as is the process of trial by jury.

Courts of summary jurisdiction have a large and varied number of duties to perform and the time at their disposal to try serious or difficult issues of fact is usually limited. It is asking too much, according to these critics, to expect them to dispose of cases with as much care, deliberation and precision as do the higher courts of trial. Moreover, judges in criminal trials are very often inclined toward the viewpoint of the prosecution; they acquire, more or less unconsciously, certain mental traits which make it extremely difficult for them to consider the explanation offered by the defendant without a certain tinge of skepticism. Hearing so many incredible stories, they sometimes fail to discern the occasional spark of truth. What is needed, it is said, as a corrective of such a tendency, is the common sense and impartial judgment of the average man.

The fact that magistrates are required by the law to consider "the character and antecedents of the accused" in determining whether the offense is one which should be dealt with summarily is another factor which would seem to militate against the defendant in a summary trial. While the knowledge that the prisoner has a record of prior convictions must, in legal theory, be used solely for the purpose of deciding whether the case is a proper one to be tried in a court of summary jurisdiction, it is difficult to beheve that, in cases where the magistrates assume jurisdiction, they will not be unconsciously influenced by the information they have acquired. Mr. Justice Avory, indeed, once pointed out that "it is obviously improper that the justices should inquire into the character and antecedents of the accused person until after they have determined upon the evidence that he ought to be convicted.... If they once did that the defendant would be entitled to come to this court afterwards to quash the conviction on the ground that they had been improperly biased by evidence of his previous convictions before they came to a conclusion as to his guilt in the particular case." ${ }^{\prime 44}$ The present law, however, following a similar provision in the Summary Jurisdiction Act of 1879 , empowers the justices to assume jurisdiction "at any time during the hearing of a charge for such an indictable offense;" ${ }^{\prime 45}$ and there seems to be no question of the fact that in order to discharge their duties under the law the justices must do, either directly or indirectly, precisely what the learned judge thought they ought not to do. ${ }^{46}$

Some courts attempt to get around the difficulty by asking the police

44 R. v. Hertfordshire JJ. (1910), 75 J. P. 91.

$45 \$ 24$ (2).

46 See the discussion of this topic in LIEck and Morrison, The Cramnar JusTICE ACr, 1925 (1926) 54. 
officer at the outset whether there is any reason why the case should not be dealt with summarily. The officer, having in mind the "character and antecedents" of the accused, rephes "Yes" or "No" and the magistrate is usually governed accordingly. The same problem often arises when the magistrate is called upon to decide whether or not to admit the defendant to bail; evidence of prior convictions may have an important bearing on the matter but there is no question but that such knowledge makes it difficult to decide the case strictly on its merits, if the court subsequently determines to dispose of it summarily.

Almost all of the foregoing arguments resolve themselves into a defense of the institution of trial by jury as opposed to trial by judges. Those who doubt the wisdom of laws permitting the summary disposition of indictable offenses concede that judges may be the more expert but maintain that it is better that many guilty defendants should escape than that any innocent persons should be convicted. Those who favor the new procedure believe that, on the whole, it offers a satisfactory substitute for the jury. They maintain that apparent defects in the admimstration of the law are far from indicating anything fundamentally wrong with the principle involved and will be remedied in the light of fuller experience. They prophesy that the time is not far distant when courts of summary jurisdiction will be authorized to try even more important cases and to inflict severer punishments. They point to the fact that summary trials are more expeditious and less expensive than trials upon indictment. They argue that there can be no harm in permitting magistrates to try indictable offenses when the circumstances disclose no special reasons why the cases should be sent to the higher courts. Magistrates, it is said, are competent to determine whether the punishment they are authorized to inflict is sufficient to meet the ends of justice. The important consideration is not the technical charge to which the defendant pleads guilty or of which he is convicted, but whether he has been fairly convicted and adequately sentenced. It is urged, moreover, that there are probably fewer miscarriages of justice in cases disposed of summarily than before juries. ${ }^{47}$

47 Of the 69,695 persons charged with indictable offenses and dealt with summarily during the year $1926,62,043$, or roughly $89 \%$, were convicted, if we include as convictions those cases in which the charges were held to have been proved and the defendants, without technically being convicted, were either placed on probation or their recognizances taken to keep the peace, or to come up for judgment, if called upon to do so. Of the 7,924 persons committed for trial during the same year at assizes and quarter sessions, 6,350 , or about $80 \%$, were convicted. It must also be borne in mind that in the lower, as in the higher courts, pleas of guilty are recorded as convictions, or cases proved. See CRmmirat Statrstics (1926) Cind. 3055, pp. 51, 107. Even though the percentage of convictions is higher in the summary trials of indictable offenses than in those tried upon indictment, it does not follow that there is any tendency on the part of magistrates to deal unfairly with the accused. The 
It must be conceded, I think, that the Criminal Justice Act resulted in large part from a recognition by Parliament of the efficient manner in which courts of summary jurisdiction discharged their functions during the war period. It is significant that outside of London and some of the larger cities these courts are composed of unpaid lay justices of the peace, men of experience and judgment who represent all sections of the community and bring to the bench many of the qualities that an intelligent jury is expected to possess. The court of trial sometimes approximates in actual number the twelve good men who try indictments, although, of course, a unanimous verdict is not required. It is said that the justices have the tendency, sonietimes so marked in a jury, to ignore considerations of strict law, upon which they are constantly advised by their professional clerk, in an effort to dispense what they consider to be substantial justice. That it is only a question of time until the jurisdiction of summary courts will be further enlarged is the opimion of nost experienced observers of the situation. A recent commentator in an English legal review referred to the new law as "simply another long step on the road toward the replacement of the jury by the justice."

Pendleton Howard.

College of LaW,

UNIVERSITY OF IDAHO

fact that juries try a higher proportion of dificult cases, in which the evidence is more complicated and contradictory and in which the testimony of the individual witnesses has frequently deteriorated in value due to the lapse of time hetween the committal and the trial, is only one of several important factors in the situation which tend to produce a higher percentage of convictions in cases disposed of summarily. Moreover, in England, as in the United States, juries are apt to be unduly lenient in certain types of cases and to bring in verdicts contrary to the evidence.

48 (1926) 161 LAW T. 91. Such a view seems to be substantiated by the recent recommendation of the Department Committee on Summary Offenses against Young Persons that summary trials should be permitted in all offenses of gross indecency and attempts at incest with, or carnal knowledge of, females under sixteen years. See Paretamentary Papers (1924-5) vol. XV, Cmd. 2561, p. 905. It is interesting to note that Sir Archibald Bodkin, the Director of Public Prosecutions, is a strong advocate of the optional non-jury trial. "There are those," he writes, "who regard it as a soinewhat doubtful experiment in the law to confer an enlarged jurisdiction on justices in Quarter Sessions and in Petty Sessions over criminal cases. I do not so regard it, and feel confident that with increased responsibilities justices will 'rise to the occasion' and discharge their duties as satisfactorily as hitherto." LIECK AND Morrison, The Crmatnal Justice Act, 1925 (1926) foreword, p. xxv. 